EXTENDED REPORT

\title{
Electrophysiological characterisation and monitoring in the management of birdshot chorioretinopathy
}

\author{
G E Holder, A G Robson, C Pavesio, E M Graham
}

Br J Ophthalmol 2005;89:709-718. doi: 10.1136/bjo.2004.047837

See end of article for authors' affiliations ....................

Correspondence to: Dr G E Holder, Department of Electrophysiology, Moorfields Eye Hospital, City Road, London ECIV 2PD, UK; graham.holder@ moorfields.nhs.uk

Accepted for publication 3 November 2004

\begin{abstract}
Aims: To characterise patients with birdshot chorioretinopathy (BCR) clinically and electrophysiologically in order to monitor changes in retinal function before and after treatment with corticosteroids and/or immunosuppression.

Methods: 18 patients with BCR were characterised clinically and electrophysiologically. Serial studies were performed on 14 patients in order to monitor changes in retinal function before and after treatment with corticosteroids and/or immunosuppression.

Results: Most patients presented with characteristic subretinal pale spots, were HLA-A29 positive, and had diverse signs of ocular inflammation. Various electrophysiological abnormalities were present. Moderately severe bilateral pattern electroretinogram (PERG) abnormalities at presentation were common, reflecting macular dysfunction. Cone mediated $30 \mathrm{~Hz}$ flicker electroretinograms (ERGs) were consistently delayed before treatment, and were the most sensitive parameter of retinal dysfunction. Scotopic maximal ERG responses were abnormal in 13 patients; 10 had an electronegative maximal ERG or a reduced b:a ratio in one or both eyes. Single flash photopic ERGs were less often and less severely affected. Photopic ON and OFF ERG responses often revealed predominant $\mathrm{ON}$ response $b$-wave abnormalities with relative OFF response preservation. ERGs improved in treated cases, sometimes preceding clinical signs of recovery. Pattern ERG improvements occurred, possibly reflecting the resolution of macular oedema.

Conclusions: The ERG data confirm that BCR frequently affects inner retinal function of cone and rod systems. Clinical features were not reliable indicators of functional deterioration or recovery. Objective electrophysiological assessment of retinal function demonstrated improvement following treatment and provides a reliable method of monitoring treatment efficacy, enabling management decisions to be taken with greater confidence and allowing early initiation or modification of treatment.
\end{abstract}

$\mathrm{B}$ irdshot chorioretinopathy (BCR) is a chronic inflammatory disorder, usually bilateral, and usually characterised by multiple discrete cream coloured areas of subretinal hypopigmentation, vitritis, cystoid macular oedema (CMO), and retinal vasculitis. ${ }^{1-3}$ Disc oedema may be present, and in end stage disease vascular attenuation and optic disc pallor may be seen. The creamy white areas of depigmentation may be confluent, or may radiate outwards from the optic disc, and are not usually seen in the very early stages. In the latter stages of the disease they may become atrophic. ${ }^{4}$ There is a strong association with the HLA-A29 antigen $^{5-7}$ and most affected patients are HLA-A29 positive. ${ }^{9}$ A recent report of histopathology in a human eye showed lymphocytic aggregations in the choroid, retinal vasculature and optic nerve head, ${ }^{10}$ similar to that seen in HLA-A29 transgenic mice. ${ }^{11}$ Most patients describe an insidious onset of floaters, preceding reduced acuity caused by CMO, which takes them to the ophthalmologist. Nyctalopia, photopsia, visual field constriction, and colour vision deficits are commonly reported.

Unfortunately, BCR has a protracted but highly unpredictable and recurrent clinical course that does not facilitate management decisions. Indication for treatment is not always clear, and there are difficulties ascertaining the influence of therapy on visual outcome. ${ }^{3}$ Currently, there is no consensus on the appropriate methods for assessing the efficacy of treatment. Visual acuity (VA) may be used, but it is not a satisfactory indicator of generalised retinal function. ${ }^{12}{ }^{13}$ Equally, clinical parameters, such as the degree of intraocular inflammation, may not accurately reflect the degree of retinal dysfunction. Objective criteria for initiating and monitoring treatment, such as provided by electrophysiology, may make a valuable contribution to patient care.

Early reports of electroretinogram (ERG) changes in BCR suggested possible inner retinal dysfunction ${ }^{14}$ with eventual additional outer retinal involvement. ${ }^{13}{ }^{15}$ This report describes our experience with electrophysiological evaluation of patients with BCR, which confirms that marked ERG changes may occur when symptoms are only mild or absent, and that electrophysiological monitoring can determine when retinal function has been restored consequent upon treatment. It has become our view that electrophysiological investigation not only provides objective criteria for the efficacy of treatment, but also can be an indicator for the initiation or restitution of treatment.

\section{METHODS}

A cohort of 18 patients with BCR is described. All were clinically ascertained (table 1) and received electrophysiological assessment. This incorporated full field ERGs in order to monitor generalised retinal function and pattern electroretinogram (PERG) to assess macular function. Many patients also had electro-oculogram (EOG) recording to examine the function of the retinal pigment epithelium/ photoreceptor complex, and ON and OFF response ERG recording separately to examine the function of the photopic $\mathrm{ON}$ and OFF pathways.

Abbreviations: $\mathrm{BCR}$, birdshot chorioretinopathy; $\mathrm{CMO}$, cystoid macular oedema; EOG, electro-oculogram; ERG, electroretinogram; PERG, pattern electroretinogram; $V A$, visual acuity 





The full field ERG protocol incorporated the ISCEV standard rod specific and maximal ERGs, both recorded under dark adaptation, and the photopic $30 \mathrm{~Hz}$ flicker and single flash ERGs, both recorded after a standard period and intensity of light adaptation. ${ }^{16}$ All eyes were dilated before full field testing using tropicamide (1\%) and/or phenylephrine hydrochloride (2.5\%). ISCEV standard pattern ERGs were performed ${ }^{17}$ without mydriasis; EOGs were also recorded to ISCEV standard. ${ }^{18}$

Long duration photopic stimulation was used to record ON and OFF ERG responses using previously described techniques. $^{19}{ }^{20}$ In brief, an amber stimulus of $120 \mathrm{~ms}$ or $200 \mathrm{~ms}$ duration (luminance $560 \mathrm{~cd} / \mathrm{m}^{2}$ ) was presented upon a bright green background (luminance $160 \mathrm{~cd} / \mathrm{m}^{2}$ ) close to peak rod spectral sensitivity and thus suitable to suppress rod function. Colour contrast sensitivity was measured psychophysically in all patients by determining thresholds along isoluminant protan, deutan, and tritan colour confusion axes using the Arden colour contrast sensitivity system. ${ }^{21}$

Some patients had follow up recordings over varying time scales. The alterations in electrophysiology are described.

\section{RESULTS}

The incidence of the common symptoms and signs found on examination of the 18 patients is shown in table 1 . The constellation of symptoms varied between patients but could include floaters (12 cases), field loss (10 cases), visual distortion (nine cases) and/or visual acuity loss (seven cases), photopsiae (nine cases), colour vision problems (nine cases) and nyctalopia (seven cases). The characteristic hypochromic birdshot lesions were seen in 15/18 patients at presentation. Sixteen patients had signs of vitritis and 15 had signs of vasculitis and/or vessel attenuation. Other signs varied but often included disc pallor, disc oedema and CMO. HLA-A29 status was not ascertained in two clinically definite patients (cases 12 and 13); all others were HLA-A29 positive.

The electrophysiological findings in 18 patients are summarised in table 2. The initial electrophysiological abnormalities were usually bilateral but interocular asymmetries were often observed; only one patient with very mild disease had unilateral abnormalities (case 12). Photopic cone flicker ERGs were consistently delayed in at least one eye of all patients. Single flash photopic ERGs were less often and less severely affected. Photopic ON and OFF ERG responses in $12 / 13$ patients revealed predominant ON b-wave abnormalities with relative ( 10 patients) or complete (two patients) preservation of the OFF d-wave. Scotopic maximal ERG responses were abnormal in 13 patients; six had (electro) negative maximal ERG responses, or a reduced b:a ratio in both eyes, and a further four showed unilateral b-wave reduction. One patient with a 15 year history (case 7) had an electronegative maximal ERG with a subnormal a-wave, in keeping with a degree of additional photoreceptor loss.

Eight out of 12 cases showed improvement in clinical signs following systemic treatment with steroids and/or immunosuppressives (table 3 ). Inflammatory signs such as vitritis and vasculitis often improved initially but rebound inflammation occurred in six cases as high dose systemic medication was tapered (cases 3, 6, 10, 13, 14, and 18). Two of the patients who did not improve had treatment withdrawn after

Table 2 Summary of electrophysiological findings at presentation

\begin{tabular}{|c|c|c|c|c|c|c|c|c|}
\hline \multirow[b]{2}{*}{ Case } & \multirow[b]{2}{*}{ Age (years) } & \multirow[b]{2}{*}{ Pattern ERG } & \multicolumn{2}{|c|}{ Scotopic ERGs } & \multicolumn{4}{|l|}{ Photopic ERGs } \\
\hline & & & Rod specific & Maximal & $30 \mathrm{~Hz}$ flicker & Single flash & ON b-wave & OFF $d$-wave \\
\hline \multirow[t]{2}{*}{1} & 55 & $A$ & $A$ & A -ve & A & $N$ & A-ve & $N$ \\
\hline & & A & A & $A-v e$ & A & $A$ & A-ve & $N$ \\
\hline \multirow[t]{2}{*}{2} & 56 & $A$ & $A$ & A & $A$ & $\mathrm{~N}$ & $A$ & $\mathrm{~N}$ \\
\hline & & $N$ & $A$ & $A$ & $\mathrm{~N}$ & $\mathrm{~N}$ & $\mathrm{~N}$ & $\mathrm{~N}$ \\
\hline \multirow[t]{2}{*}{3} & 38 & $A$ & $A$ & $\mathrm{~N}$ & A & $\mathrm{N}$ & - & - \\
\hline & & A & $A$ & $\mathrm{~N}$ & A & $\mathrm{N}$ & - & - \\
\hline \multirow[t]{2}{*}{4} & 55 & $A$ & $A$ & A -ve & $A$ & A & $A-v e^{*}$ & $\mathrm{~A}(\mathrm{mild})^{*}$ \\
\hline & & A & $A$ & $A-v e$ & A & A & $A-v e^{*}$ & $A($ mild)* \\
\hline \multirow[t]{2}{*}{5} & 62 & A & $A$ & A -ve & A & $A$ & $A-v e$ & $\mathrm{~N}$ \\
\hline & & A & $A$ & A -ve & A & A & A-ve & $N$ \\
\hline \multirow[t]{2}{*}{6} & 65 & $A$ & $\mathrm{~N}$ & $N$ & $A$ & $A$ & $A$ & $\mathrm{~N}$ \\
\hline & & $A$ & $N$ & $\mathrm{~N}$ & $A$ & $\mathrm{~A}$ & A & $\mathrm{N}$ \\
\hline \multirow[t]{2}{*}{7} & 60 & A & $A$ & A-ve (low a) & A & A & A-ve & A (mild) \\
\hline & & A & $A$ & A-ve (low a) & A & $A$ & A-ve & A (mild) \\
\hline \multirow[t]{2}{*}{8} & 46 & A & $A$ & A -ve & A & $A$ & A-ve & $\mathrm{N}$ \\
\hline & & A & $\mathrm{N}$ & $\mathrm{N}$ & $\mathrm{N}$ & $\mathrm{N}$ & - & - \\
\hline \multirow[t]{2}{*}{9} & 49 & A & $\mathrm{N}$ & $\mathrm{N}$ & A & $A$ & - & - \\
\hline & & A & $\mathrm{N}$ & $N$ & $A$ & $A$ & - & - \\
\hline \multirow[t]{2}{*}{10} & 45 & A & $A$ & A -ve & A & $N$ & $A-v e^{*}$ & $\mathrm{~N}^{*}$ \\
\hline & & A & $A$ & $A-v e$ & A & $N$ & - & - \\
\hline \multirow[t]{2}{*}{11} & 30 & A & $A$ & A-ve & $A$ & $A$ & $A$ & $\mathrm{~N}$ \\
\hline & & A & $A$ & A & A & $\mathrm{N}$ & $\mathrm{N}$ & $\mathrm{N}$ \\
\hline \multirow[t]{2}{*}{12} & 26 & $N$ & $N$ & $N$ & $\mathrm{~N}$ & $N$ & - & - \\
\hline & & A & $\mathrm{N}$ & $\mathrm{N}$ & A & $N$ & - & - \\
\hline \multirow[t]{2}{*}{13} & 51 & A & $A$ & A-ve & A & $A$ & $A$ & $\mathrm{~N}$ \\
\hline & & A & $A$ & A-ve & A & A & A & $\mathrm{N}$ \\
\hline \multirow[t]{2}{*}{14} & 52 & A & $A$ & A (low b:a) & A & $A$ & A -ve & $\mathrm{N}$ \\
\hline & & A & $\mathrm{N}$ & $\mathrm{N}$ & A & $\mathrm{N}$ & - & - \\
\hline \multirow[t]{2}{*}{15} & 64 & A & $\mathrm{N}$ & A-ve & A & $A$ & $A$ & $A$ \\
\hline & & A & A & A & A & A & - & - \\
\hline \multirow[t]{2}{*}{16} & 49 & A & $\mathrm{N}$ & $A$ & A & $\mathrm{N}$ & - & - \\
\hline & & $\mathrm{N}$ & $\mathrm{N}$ & $A$ & A & $\mathrm{N}$ & - & - \\
\hline \multirow[t]{2}{*}{17} & 44 & $N$ & $\mathrm{~N}$ & $\mathrm{~N}$ & $A$ & $A$ & A $(\text { low } b ; a)^{*}$ & $\mathrm{~N}^{*}$ \\
\hline & & $A$ & $\mathrm{~N}$ & $A$ & A & $A$ & A (low b:a)* & $\mathrm{N}^{*}$ \\
\hline \multirow[t]{2}{*}{18} & 62 & A & $\mathrm{N}$ & $\mathrm{N}$ & A & $N$ & $\mathrm{~N}$ & $N$ \\
\hline & & A & $\mathrm{N}$ & $N$ & A & $N$ & $\mathrm{~N}$ & $\mathrm{~N}$ \\
\hline
\end{tabular}


Table 3 Summary of ERG monitoring and follow up in the 18 patients; nine of 10 patients showed improvement in full field ERGs following systemic treatment

\begin{tabular}{|c|c|c|c|c|c|c|c|}
\hline Case & EDD visits & Treatment & $\begin{array}{l}\text { VA before } \\
\text { treatment }\end{array}$ & $\begin{array}{l}\text { VA after } \\
\text { treatment }\end{array}$ & PERG P50 changes & Full field ERG changes & Clinical changes \\
\hline 1 & $5(19)$ & $\begin{array}{l}\text { Oral } \\
\text { prednisolone }\end{array}$ & $\begin{array}{l}6 / 9 \\
6 / 12\end{array}$ & $\begin{array}{l}6 / 6 \\
6 / 6\end{array}$ & See text & See text & $\begin{array}{l}\text { Developed pale discs, vessel sheathing and } \\
\text { early lens opacities over } 2 \text { years following } \\
\text { treatment. VA stable }\end{array}$ \\
\hline 2 & $4(16)$ & $\begin{array}{l}\text { Oral } \\
\text { prednisolone }\end{array}$ & $\begin{array}{l}6 / 9 \\
6 / 9\end{array}$ & $\begin{array}{l}6 / 12 \\
6 / 5\end{array}$ & See text & See text & Mild clinical improvement \\
\hline 3 & $11(43)$ & $\begin{array}{l}\text { Oral } \\
\text { prednisolone } \\
\text { and cyclosporin }\end{array}$ & $\begin{array}{l}6 / 12 \\
6 / 6\end{array}$ & $\begin{array}{l}6 / 9 \\
6 / 6\end{array}$ & See text & See text & $\begin{array}{l}\text { Treatment improved inflammatory signs but } \\
\text { had little impact on VA or CMO. Subjectively } \\
\text { and clinically stable }\end{array}$ \\
\hline 4 & $10(82)$ & $\begin{array}{l}\text { Oral } \\
\text { prednisolone } \\
\text { (1 course) }\end{array}$ & $\begin{array}{l}6 / 9 \\
6 / 9\end{array}$ & $\begin{array}{l}6 / 6 \\
6 / 9\end{array}$ & $\begin{array}{l}\text { Initial deterioration } \\
\text { then some fluctuation }\end{array}$ & Deterioration & $\begin{array}{l}\text { Prednisolone withdrawn due to systemic } \\
\text { complications. Gradual mild worsening of } \\
\text { VA over } 4 \text { years, vascular sheathing }\end{array}$ \\
\hline 5 & $5(70)$ & - & - & - & Deterioration & Deterioration RE & $\begin{array}{l}\text { Mild subjective worsening of vision LE }>\text { RE. } \\
\text { Pale spots manifest } 2.5 \text { years after } \\
\text { presentation }\end{array}$ \\
\hline 6 & $3(15)$ & $\begin{array}{l}\text { Oral } \\
\text { prednisolone } \\
\text { and azathioprine }\end{array}$ & $\begin{array}{l}6 / 9 \\
6 / 9\end{array}$ & $\begin{array}{l}6 / 9 \\
6 / 6\end{array}$ & $\begin{array}{l}\text { Marked improvement } \\
\text { both eyes followed } \\
\text { by deterioration as } \\
\text { medication was } \\
\text { reduced }\end{array}$ & $\begin{array}{l}\text { Improved following } \\
\text { treatment but mild } \\
\text { deterioration as } \\
\text { medication was } \\
\text { tapered }\end{array}$ & $\begin{array}{l}\text { Subjective improvement in VA. Vasculitis and } \\
\text { CMO improved but recurrent inflammation } \\
\text { and epiretinal membranes developed as } \\
\text { medication was tapered. }\end{array}$ \\
\hline 7 & $\begin{array}{l}3 \\
\text { (16 years) }\end{array}$ & $\begin{array}{l}\text { Oral } \\
\text { prednisolone } \\
15 \text { years earlier }\end{array}$ & - & - & $\begin{array}{l}\text { Subnormal } 15 \text { years } \\
\text { earlier. Undetectable } \\
\text { over the past } \\
16 \text { months }\end{array}$ & $\begin{array}{l}\text { Profound deterioration } \\
\text { over } 15 \text { years but } \\
\text { stable over the past } \\
16 \text { months }\end{array}$ & $\begin{array}{l}\text { Increasing annular scotoma and extensive } \\
\text { chorioretinal degeneration over } 15 \text { years } \\
\text { with sparing of central maculae, now stable }\end{array}$ \\
\hline 8 & $4(67)$ & $\begin{array}{l}\text { Orbital floor } \\
\text { injections of } \\
\text { triamcinolone } \\
\text { then oral } \\
\text { prednisolone }\end{array}$ & $\begin{array}{l}6 / 60 \\
6 / 12\end{array}$ & $\begin{array}{l}6 / 24 \\
6 / 9\end{array}$ & $\begin{array}{l}\text { Subnormal but stable } \\
\text { with orbital floor } \\
\text { injections. Marked } \\
\text { improvement with oral } \\
\text { prednisolone, } \\
\text { associated with } \\
\text { reduced CMO }\end{array}$ & $\begin{array}{l}\text { Slight deterioration } \\
\text { while being treated } \\
\text { with orbital floor } \\
\text { injections. Marked } \\
\text { improvement with } \\
\text { oral prednisolone }\end{array}$ & $\begin{array}{l}\text { Orbital floor injections initially reduced } \\
\text { ocular inflammation and periphlebitis but RE } \\
\text { VA suddenly fell to } 6 / 60 \text {. Marked bilateral } \\
\text { improvement in vitritis, CMO, and VA on } \\
\text { systemic steroids. }\end{array}$ \\
\hline 9 & $3(18)$ & Not treated & - & - & Improved & Stable & $\begin{array}{l}\text { Mild subjective worsening of vision. Disc } \\
\text { oedema and vasculitis improved without } \\
\text { treatment. Developed inferior bilateral } \\
\text { atrophic scars }\end{array}$ \\
\hline 10 & $4(33)$ & $\begin{array}{l}\text { Oral } \\
\text { prednisolone } \\
\text { and cyclosporin }\end{array}$ & $\begin{array}{l}6 / 9 \\
6 / 9\end{array}$ & $\begin{array}{l}6 / 5 \\
6 / 6\end{array}$ & $\begin{array}{l}\text { Subnormal but stable } \\
\text { in the presence of } \\
\text { persistent CMO }\end{array}$ & $\begin{array}{l}\text { Improved initially, } \\
\text { then deterioration as } \\
\text { treatment was tapered }\end{array}$ & $\begin{array}{l}\text { Improvement in VA within } 2 \text { weeks but with } \\
\text { persistent CMO. Inflammatory signs became } \\
\text { quiescent but recurred when medication was } \\
\text { tapered. Increasing steroids controlled } \\
\text { rebound inflammation but disc pallor slowly } \\
\text { worsening }\end{array}$ \\
\hline 11 & 1 & Not treated & - & - & - & - & $\begin{array}{l}\text { Mild deterioration in VA over } 34 \text { months, } \\
\text { Developed photopsias in LE, otherwise stable. }\end{array}$ \\
\hline 12 & 1 & $\begin{array}{l}\text { Topical } \\
\text { Betamethasone }\end{array}$ & - & - & - & - & $\begin{array}{l}\text { Worsening VA over } 3 \text { years. Clinically stable } \\
\text { over } 10 \text { months }\end{array}$ \\
\hline 13 & $3(38)$ & $\begin{array}{l}\text { Oral } \\
\text { prednisolone } \\
\text { and cyclosporin }\end{array}$ & $\begin{array}{l}6 / 12 \\
6 / 12\end{array}$ & $\begin{array}{l}6 / 9 \\
6 / 9\end{array}$ & $\begin{array}{l}\text { Improvement associated } \\
\text { with reduced CMO }\end{array}$ & Improved & $\begin{array}{l}\text { VA stable over } 15 \text { months but fluctuating } \\
\text { signs including CMO, floaters, and mild } \\
\text { perceptual disturbance as cyclosporin was } \\
\text { tapered. Essentially stable over following } \\
18 \text { months on low dose cyclosporin }\end{array}$ \\
\hline 14 & 1 & $\begin{array}{l}\text { Oral } \\
\text { prednisolone } \\
\text { and cyclosporin }\end{array}$ & $\begin{array}{l}6 / 5 \\
6 / 5\end{array}$ & $\begin{array}{l}6 / 6 \\
6 / 5\end{array}$ & - & - & $\begin{array}{l}\text { Gradual deterioration in VA over } 3 \text { years. } \\
\text { Clearer vitreous following high dose therapy } \\
\text { but fresh BCR lesions on right and worsening } \\
\text { of vitritis as medication was tapered. Right } \\
\text { macula developed RPE changes, posterior } \\
\text { vitreous detachment LE }\end{array}$ \\
\hline 15 & $3(36)$ & $\begin{array}{l}\text { Oral } \\
\text { prednisolone }\end{array}$ & $\begin{array}{l}6 / 18 \\
6 / 24\end{array}$ & $\begin{array}{l}6 / 12 \\
6 / 12\end{array}$ & Undetectable & $\begin{array}{l}\text { Mild improvement. } \\
\text { Deterioration since } \\
\text { medication was } \\
\text { tapered }\end{array}$ & $\begin{array}{l}\text { Gradual improvement in VA and colour } \\
\text { vision and slight reduction in vitritis over } \\
2 \text { years. Intraretinal bleeding associated with } \\
\text { high BP. Slight reduction in VA but clinically } \\
\text { stable for } 2 \text { years since therapy ceased. }\end{array}$ \\
\hline 16 & 1 & $\begin{array}{l}\text { Oral } \\
\text { prednisolone } \\
\text { (1 course) } \\
\text { Depot steroids }\end{array}$ & $\begin{array}{l}6 / 9 \\
6 / 9\end{array}$ & $\begin{array}{l}6 / 9 \\
6 / 9\end{array}$ & - & - & $\begin{array}{l}\text { Prednisolone withdrawn due to raised BP (no } \\
\text { subjective improvement). Periocular depot } \\
\text { steroids initially resulted in reduced floaters } \\
\text { and vitritis but recurrence of vitritis } 2 \text { years } \\
\text { later }\end{array}$ \\
\hline 17 & $3(71)$ & $\begin{array}{l}\text { Systemic } \\
\text { treatment refused } \\
\text { by patient. } \\
\text { Orbital floor } \\
\text { steroids }\end{array}$ & - & - & Stable & $\begin{array}{l}\text { Significant ERG } \\
\text { deterioration }\end{array}$ & $\begin{array}{l}\text { Fluctuating VA over } 8 \text { years and increased } \\
\text { photopsiae. Reported visual disturbances on } \\
\text { eye closure. Developed multiple atrophic RPE } \\
\text { lesions, macular and peripheral retinal } \\
\text { thickening, vaculitis and vascular attenuation }\end{array}$ \\
\hline 18 & $3(11)$ & $\begin{array}{l}\text { Oral } \\
\text { prednisolone }\end{array}$ & $\begin{array}{l}6 / 9 \\
6 / 12\end{array}$ & $\begin{array}{l}6 / 6 \\
6 / 9\end{array}$ & Improved & Mild improvement & $\begin{array}{l}\text { Mild improvement in VA but some fluctuation } \\
\text { in inflammatory signs when medication was } \\
\text { tapered, stable over past year }\end{array}$ \\
\hline
\end{tabular}




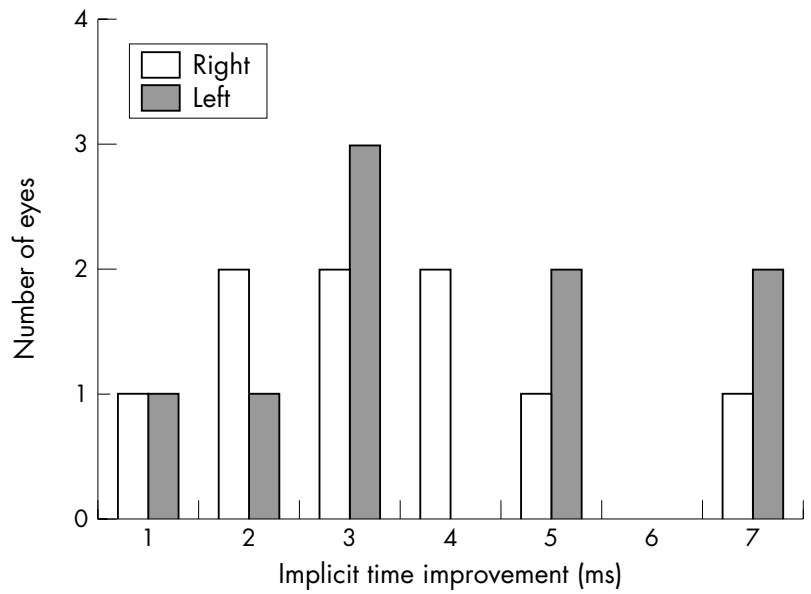

Figure 1 Histogram showing magnitude of implicit time improvement in $30 \mathrm{~Hz}$ flicker ERGs in right (open bars) and left (solid bars) eyes following systemic treatment in nine patients who were monitored longitudinally.

a single course of therapy because of systemic complications (cases 4 and 16). There was mild unilateral deterioration of visual acuity in two treated cases associated with retinal pigment epithelium (RPE) changes at the macula (case 14) or persistent CMO (case 2). Following systemic treatment, Snellen visual acuity improved by two lines (five eyes), one line ( 11 eyes) or remained stable (six eyes).

Overall, these ERG abnormalities indicate a high incidence of inner retinal dysfunction, principally affecting the ON pathways in both rod and cone systems. Moderately severe bilateral PERG abnormalities were present in 14 patients; in four the abnormality was unilateral.

Nine out of 10 patients who had serial electrophysiology showed significant improvement in full field ERGs following systemic treatment with steroids and/or immunosuppressives (table 3). The most sensitive electrophysiological parameter was the implicit time of the $30 \mathrm{~Hz}$ flicker ERG (fig 1). Pattern ERG abnormalities improved bilaterally in 6/9 cases and unilaterally in $2 / 9$ cases following systemic treatment with corticosteroids and/or immunosupression, possibly reflecting reduced macular oedema (table 3 ). Increases in PERG P50 amplitude were associated with better visual acuity in all but two cases.

One patient refused systemic treatment, only consenting to intermittent sub-Tenon's steroid injections. Initially, there was only a mildly subnormal maximal ERG response in one eye, with $30 \mathrm{~Hz}$ flicker ERG abnormalities in both eyes (case 17). Over a 5 year period there was marked ERG deterioration, with the development of an electronegative maximal ERG response in both eyes and increased abnormality of the flicker responses. The patient retained reasonably good acuity but the fundus appearance deteriorated (table 3). In case 8 , orbital floor injections improved clinical signs of inflammation but ERGs showed deterioration over the same period. This patient consented to systemic treatment only when visual acuity dropped precipitously in one eye. Oral steroids produced marked bilateral improvement; vitritis and CMO was reduced, visual acuity improved, and ERGs showed significant recovery.

Full field ERG or pattern ERG abnormality did not always correspond to the severity of clinical signs and symptoms, both of which could remain stable during periods of profound ERG deterioration (cases 1 and 2). Visual acuity and pattern ERGs could not be used to monitor treatment efficacy
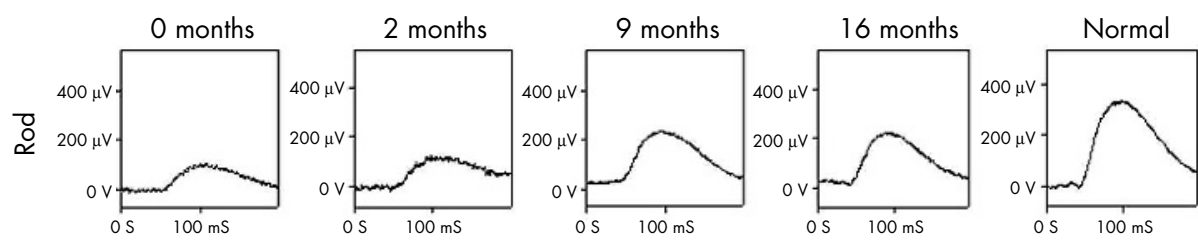

Figure 2 Pretreatment and posttreatment ERGs (case 1, right eye). Mildly electronegative ERGs showed slight deterioration over 2 months. Steroid therapy was commenced and full field ERGs normalised over the following months. Pattern ERGs
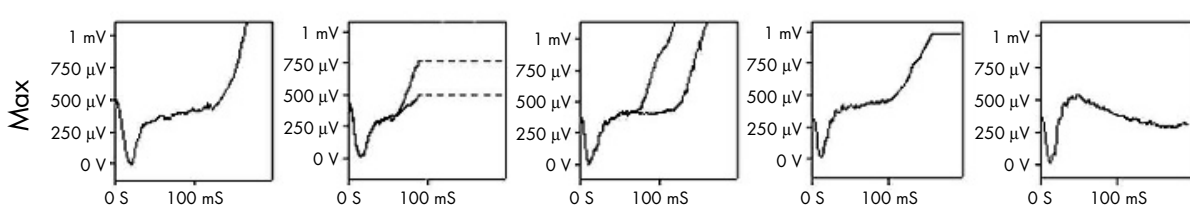
remained subnormal. See text for
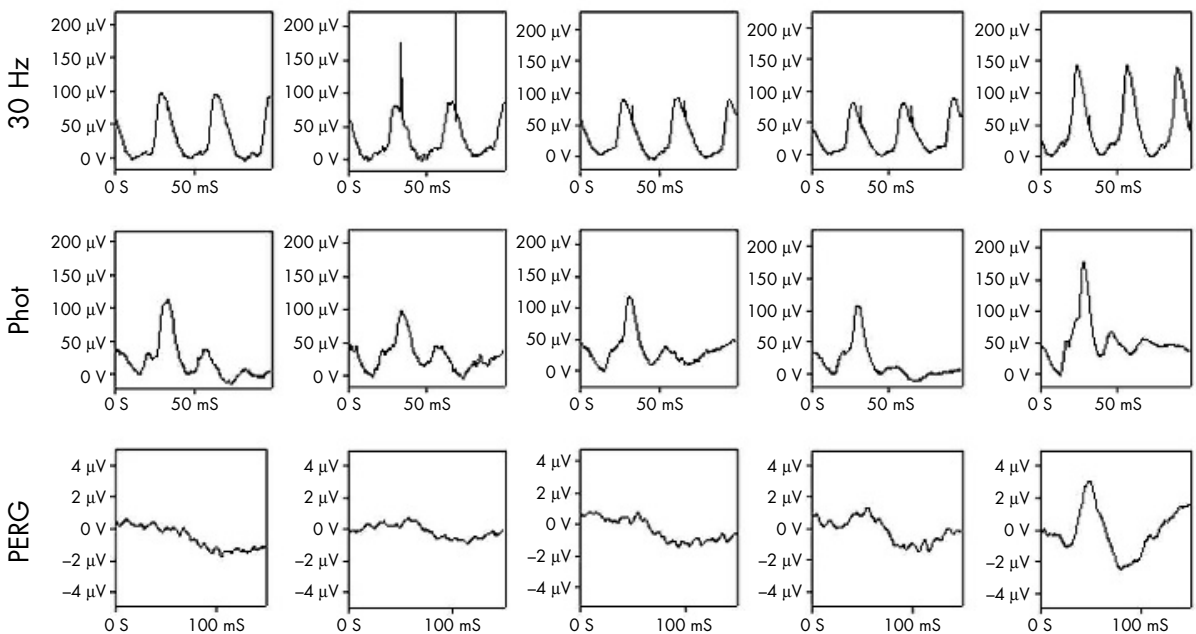
reliably; some patients had normal Snellen acuity before treatment and persistent macular oedema following therapy but normalisation of full field ERGs (see below).

Three illustrative cases are described in detail.

\section{Case 1}

A routine fundus examination by an optometrist showed unsuspected retinal abnormalities in a 55 year old woman. Subsequent close questioning revealed a 2 year history of "floaters," right eye worse than left. Detailed examination revealed the classic hypochromic lesions of BCR. There were bilateral vitreous cells and mild periphlebitis. VA was 6/9 bilaterally. The patient was HLA-A29 positive. Initial PERGs were bilaterally reduced, consistent with macular dysfunction. Colour contrast sensitivity showed elevation of the tritan threshold in both eyes. ERGs indicated generalised retinal dysfunction affecting the rod and cone systems $(R>L)$ with a reduced b:a ratio suggesting dysfunction postphototransduction (figs 2 and 3, lst columns).

The patient remained asymptomatic, other than the persistent floaters and minimal acuity reduction; 2 months later ERGs showed such severe abnormality that there was a giant a-wave and no b-wave (fig 3, second column). We have been unable to trace any previous report of an ERG abnormality of this nature. On direct questioning the patient admitted to some nyctalopia. Steroid therapy was commenced. Full field ERGs had normalised by 16 months after presentation (fig 3). PERGs improved bilaterally but remained subnormal in the right eye (fig 2). During the same period the patient developed pale discs. The patient was kept on low dose maintenance steroids, and her electrophysiology and visual acuity remained stable 30 months after presentation. Five months later some vessel sheathing and early lens opacities were noted.

\section{Case 2}

A 56 year old woman presented with photopsiae, "faded" colour perception, blurred vision and floaters in the right eye. VA was $6 / 9$ on the right and 6/6 on the left. Examination revealed pale chorioretinal spots and mild vitritis in the right eye and narrow retinal arterioles bilaterally. HLA-A29 was positive. Colour thresholds showed marginal elevation along the tritan axis but were otherwise normal. ERGs on the right were consistent with generalised retinal dysfunction affecting both rod and cone systems with significant PERG reduction indicating macular involvement. The EOG on the right revealed generalised involvement of the RPE which was disproportionately severe in relation to the degree of photoreceptor involvement. All responses on the left were normal. Four months after presentation faint pale lesions developed in the left eye. Nine months later the patient remained subjectively stable but repeat electrophysiology revealed marked deterioration in ERGs from both eyes, right worse than left, with bilateral macular involvement worse on the right (figs 4 and 5, first column). Visual acuity was 6/9 bilaterally. There was mild bilateral vitritis and vasculitis with right CMO. Treatment with high dose steroids was commenced and subsequently maintained at low levels. The ERG showed rapid improvement (figs 4 and 5, second column) and further recovery was apparent when the patient was re-examined 5 months later (figs 4 and 5, third column). However, the right PERG remained subnormal and right visual acuity reduced to $6 / 12$, probably in relation to persistent CMO.

\section{Case 3}

A 38 year old man presented with an 18 month history of floaters and "swirling" vision. VA was 6/9 on the right and $6 / 6$ on the left. Colour thresholds were elevated $(\mathrm{R}>\mathrm{L})$.
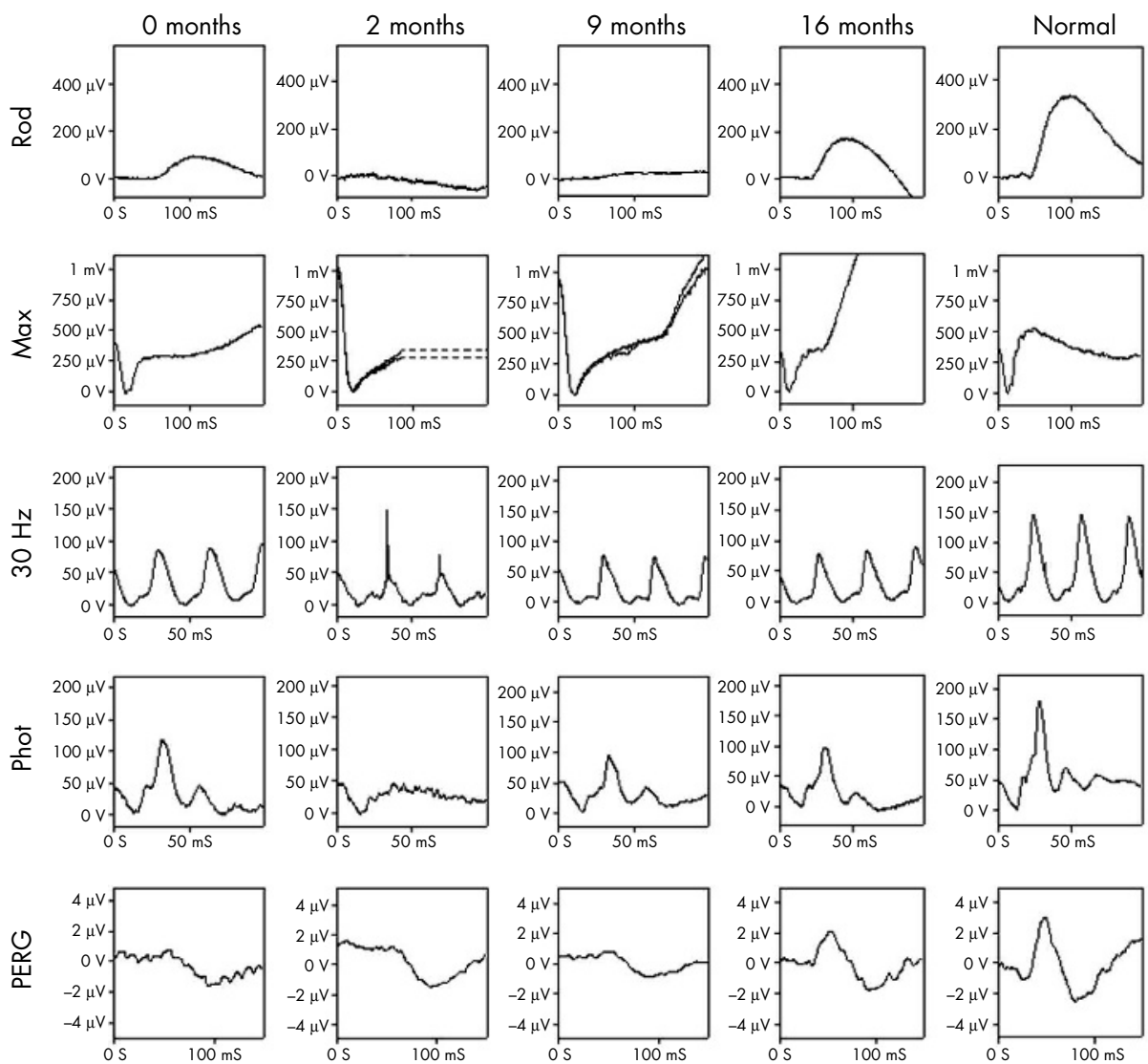

Figure 3 Pretreatment and posttreatment ERGs (case 1, left eye). Mildly electronegative ERGs showed severe deterioration over 2 months, resulting in a maximal ERG giant a-wave (row 2, column 2). Steroid therapy was commenced and full field ERGs normalised over the following months. Pattern ERGs returned to within normal limits. See text for further details. 

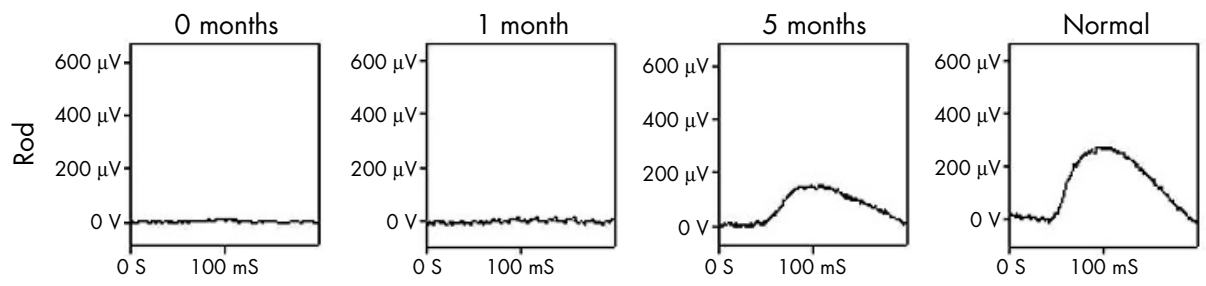

Figure 4 Pretreatment and posttreatment ERGs (case 2, right eye). All pretreatment ERGs (0 months) were delayed and reduced. ERGs showed rapid improvement following the commencement of treatment (months 1 and 5). Note the stimulus artefact in the $30 \mathrm{~Hz}$ flicker ERGs, present at $33 \mathrm{~ms}$.
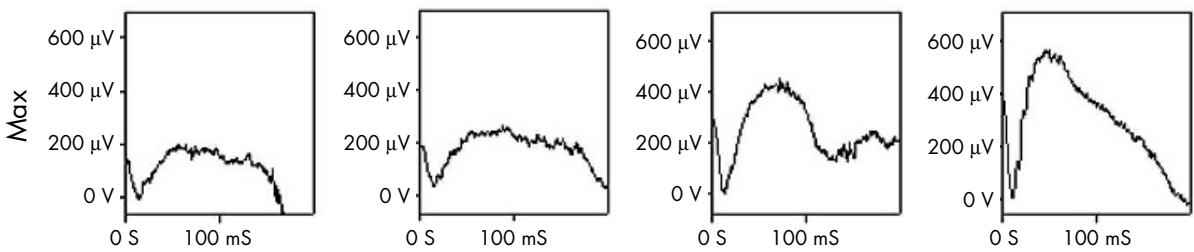

Pattern ERG remained subnormal. See ext for details.
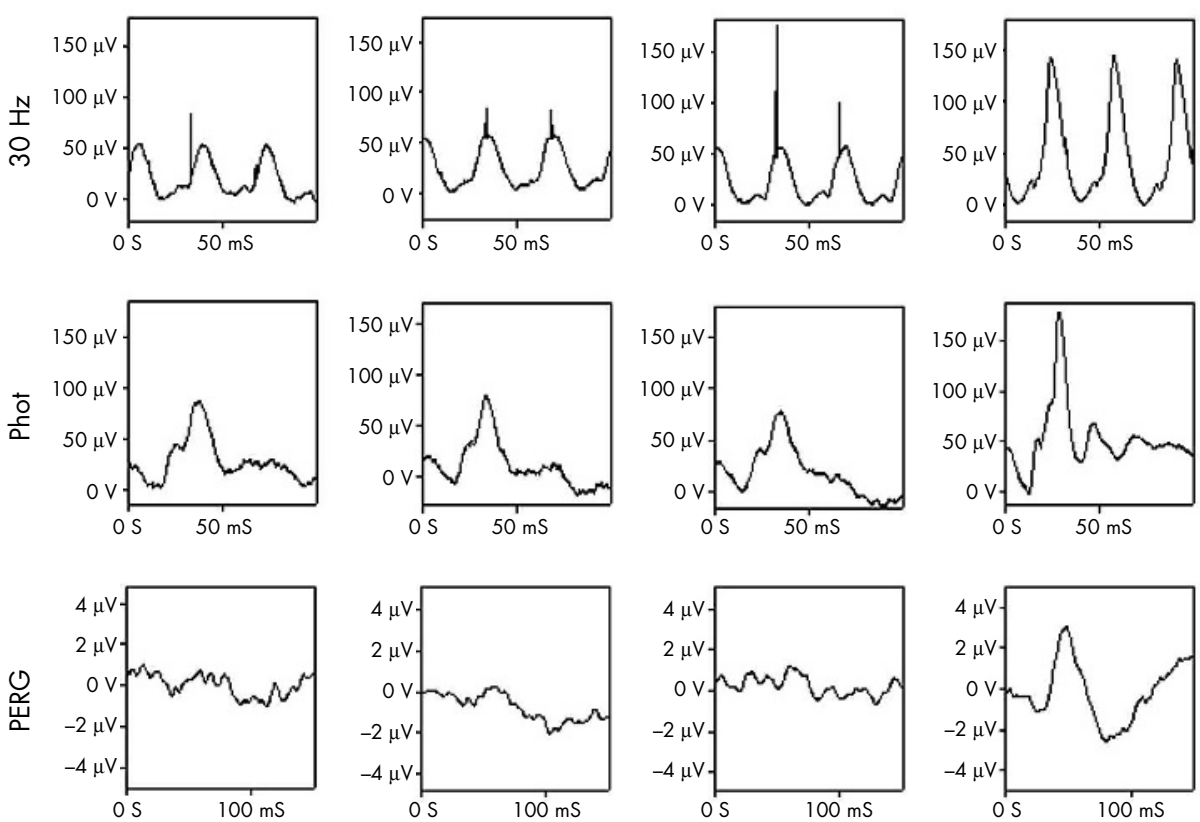

Examination revealed typical BCR lesions, vitreous cells, periphlebitis, mild disc pallor and mild CMO. HLA-A29 was positive.

The $30 \mathrm{~Hz}$ cone flicker ERGs were delayed and photopic ERGs showed a low b:a ratio. PERGs were mildly reduced bilaterally in keeping with the CMO (fig 6, month 0). Three months later, VA was $6 / 12$ and 6/9 and the patient reported difficulties in adjusting to dim light. PERGs and colour contrast sensitivity had deteriorated reflecting worsening CMO (figs 6 and 8); $30 \mathrm{~Hz}$ flicker ERGs remained abnormal with little deterioration (fig 7, months 0-6). Treatment with oral steroids and cyclosporin A had little impact on VA or CMO, but the inflammation became relatively quiescent. PERGs showed no change on the right but there was marked improvement in $30 \mathrm{~Hz}$ flicker ERGs bilaterally (fig 7, months 6-9). The improvement in electrophysiology occurred 23 weeks before the patient noticed ease of his difficulties in dim light.

Over the following 3 years this patient received episodic treatment with steroids and cyclosporin A. Serial ERGs and colour contrast sensitivity measurements were performed (figs 6, 7, and 8). The $30 \mathrm{~Hz}$ flicker ERG implicit time improved with treatment and worsened when treatment was suspended (fig 7). Central vision and visual acuity deteriorated because of worsening CMO. There was significant correlation between PERG P50 amplitude and visual acuity $(r=0.64, \mathrm{p}<0.05)$ and with colour contrast sensitivity in the right eye along deutan $(r=0.54, \mathrm{p}<0.05)$ and tritan $(r=0.56$, $\mathrm{p}<0.05$ ) axes although correlation with protan thresholds just failed to achieve significance $(r=0.5, \mathrm{p}<0.1)$. PERG and colour thresholds did not correlate with the $30 \mathrm{~Hz}$ flicker ERG, suggesting that these colour vision abnormalities relate to fluctuations in macular oedema rather than generalised cone system dysfunction. Colour thresholds in the left eye were mildly elevated and although tritan thresholds became moderately elevated, significant fluctuations were not seen. Over the following 2 years there was a slight exacerbation of inflammatory signs bilaterally, improved with systemic steroids and the patient remains subjectively and clinically stable on low dose maintenance.

\section{DISCUSSION}

Management decisions in birdshot chorioretinopathy are problematic because of the unpredictable clinical course. Electrophysiological investigation reveals a very high incidence of abnormalities, confirming previous reports, ${ }^{13} 1422$ and allows objective assessment of the degree of retinal dysfunction. The functional status of the retina in our patients with BCR could not reliably be inferred either from subjective symptoms or clinical signs, both of which could 

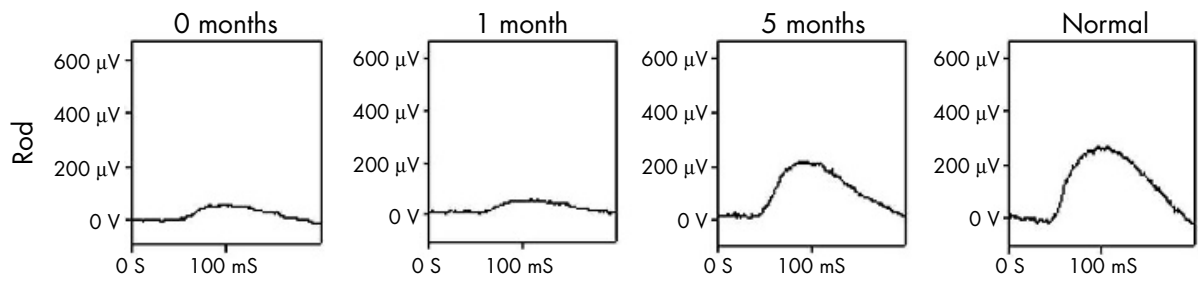

Figure 5 Pretreatment and posttreatment ERGs (case 2, left eye). All pretreatment ERGs (0 months) were delayed and reduced (less severely than on right) with the exception of the normal transient photopic ERG. ERGs show rapid improvement following treatment (months 1 and 5). Pattern
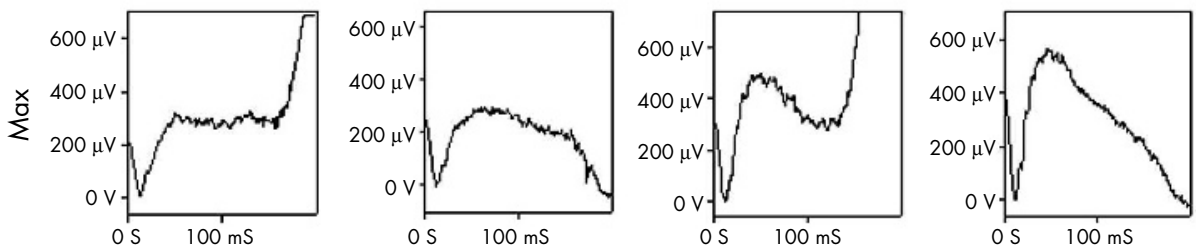

ERG also returned to normal. See text


remain stable during periods of profound deterioration in electrophysiological function. Visual acuity could not be used to monitor treatment efficacy reliably; some patients had normal Snellen acuity before treatment and some had persistent macular oedema following therapy but normalisation of full field ERGs.

The most sensitive ERG parameter for dysfunction was the $30 \mathrm{~Hz}$ cone derived flicker response, abnormal in at least one eye of all patients, consistent with a recent report describing a



Figure 6 Variation in PERG P50 component amplitude over a 42 month period in case 3 . Episodes of treatment are indicated by the rectangular blocks along the abscissa. Right eye findings are represented by circles; the left eye findings by triangles. Increases in P50 amplitude are associated with courses of treatment. See text for details. high incidence of delayed $30 \mathrm{~Hz}$ flicker ERGs in $\mathrm{BCR}^{22}$ and in keeping with the presence of retinal inflammatory disease. ${ }^{23}$ Most patients had pale spots and were HLA-A29 positive. Vitritis was the commonest sign of inflammation, present in all but two patients and vasculitis and/or vessel attenuation

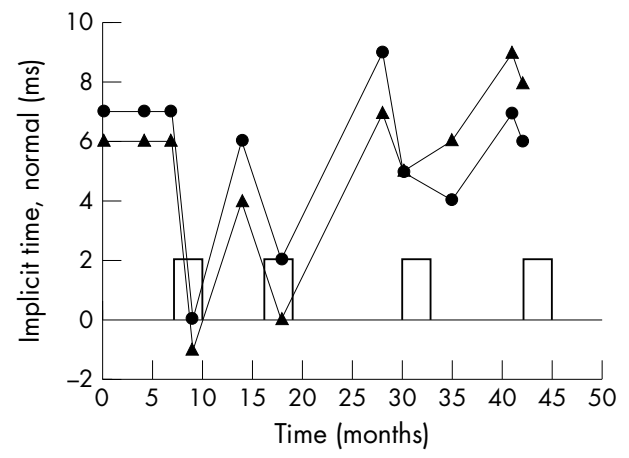

Figure 7 Variation in $30 \mathrm{~Hz}$ flicker ERG implicit time over a 42 month period in case 3. Implicit times are expressed at milliseconds above or below the upper limit of normal. Episodes of treatment are indicated by the rectangular blocks along the abscissa. Right eye findings are represented by circles; the left eye findings by triangles. Significant improvement in implicit time occurs related to episodes of treatment. See text for details. 


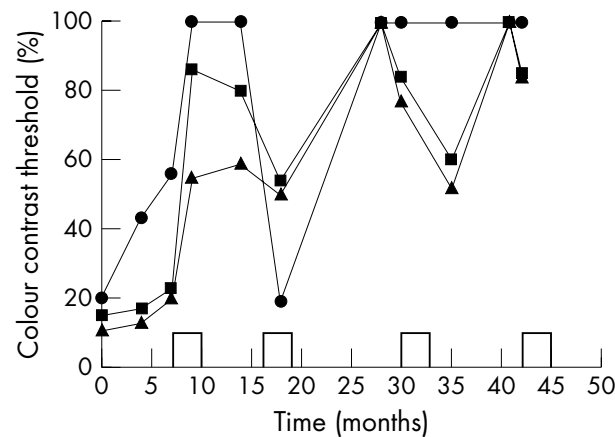

Figure 8 Variation in colour contrast thresholds over a 42 month period in case 3. Chromatic contrast is expressed as a percentage of maximum. In some instances thresholds exceeded the maximum range available and are plotted as 100\%. Episodes of treatment are indicated by the rectangular blocks along the abscissa. Chromatic axes of modulation are shown as circles (tritan), squares (protan), and triangles (deutan). Upper limit of normal is $10 \%$ for all three chromatic axes. Fluctuations in threshold occurs in association with episodes of treatment Left eye findings were mildly elevated, relatively stable and have been omitted for clarity. See text for details.

were seen in all but three. These signs were invariably accompanied by other fundus or vitreous abnormalities which often fluctuated in severity (table 3 ). In some patients symptoms and signs remained largely stable in the presence of significant ERG deterioration (cases 1 and 2). Clinical features were less accurate indicators of functional recovery as demonstrated by ERG improvement following treatment. In case 8 , orbital floor injections improved clinical signs of inflammation but ERGs showed deterioration over the same period.

It has been suggested that the retinal dysfunction in BCR primarily has an inner retinal locus. ${ }^{13-15} 2123$ Those observations are supported and extended by the results of the present study. In addition to the $30 \mathrm{~Hz}$ cone flicker ERG, arising mainly at an inner retinal level, ${ }^{24}$ a high proportion of patients had maximal ERGs that were electronegative or showed a low b:a ratio. Photopic ERGs to long duration stimuli revealed predominant ON response b-wave abnormalities with relative preservation of the ON response a-wave and OFF response d-wave in most cases. Overall, these findings are consistent with dysfunction that is primarily post-phototransduction $^{25-27}$ and probably inner retinal. Electronegative ERGs did not correspond with a specific clinical feature and were present in cases with and without hypochromic lesions; such dissociation may be predicted given their subretinal location. A recent histopathological report has shown lymphocytic aggregations associated with the retinal vasculature in a patient with BCR. ${ }^{10}$ Vasculitis and/ or vessel attenuation were common signs in the patients reported in the current study but although similar ERG abnormalities may occur in occlusive vascular disease $\mathrm{e}^{27-29}$ the reversible nature of the ERG abnormalities suggests a nonischaemic aetiology. Both cone and rod systems are affected. With time, significant outer retinal involvement could occur. There was a high incidence of impaired colour vision and in one subject monitored over an extended period (case 3), colour contrast elevation showed significant correlation with PERG abnormalities, thus probably reflecting fluctuations in macular oedema rather than generalised cone system dysfunction.

The singular findings in case 1 , where there was a "giant" a-wave, are noted. We have been unable to trace a report of similar electrophysiological findings in the literature, and believe this to be a novel finding in humans. The aetiology of this supernormal a-wave, which is of similar appearance to an isolated receptor potential ${ }^{30}$ but observed with a standard ERG stimulus, is unclear. It may be that profound inner retinal dysfunction, as suggested by the virtually unrecordable b-wave, is such that truncation of the a-wave by a normally developing b-wave does not occur. This proposal is supported by the observation that the slope of the a-wave did not differ between the two eyes. It is known that the kinetics of phototransduction are reflected in the leading edge of the a-wave. ${ }^{31}$ Although a Hood-Birch a-wave analysis ${ }^{31}$ was not performed, it is reasonable to assume that any significant difference in phototransduction kinetics between the two eyes would have manifested as an asymmetry in the a-wave slope.

There was significant improvement in retinal function in all but one patient following systemic corticosteroids and/or immunosuppression. Indeed, even very severely abnormal ERGs, such as those in case 1 , could normalise. The one exception (case 4) was a diabetic patient in whom treatment was withdrawn after a single course because of systemic complications, and in whom no significant ERG improvement occurred. The observations that normalisation of retinal function could occur following treatment, and that clinical signs were poor indicators of retinal function, has led to the adoption of a treatment strategy in which the ERG data are a vital component of the decision of when to start treatment in BCR and when treatment can be tailed off or altered to a different regime. It is reasonably assumed, when initiating treatment on the basis of an abnormal ERG, that restoration of normal function is beneficial for long term retinal health and survival. Other authors have reached similar conclusions in relation to value of ERG of assessing the efficacy of treatment; the presence of a normal $30 \mathrm{~Hz}$ response in BCR following treatment has recently been reported as a good prognostic sign, allowing tapering of immunosuppressive medication without rebound inflammation. ${ }^{22}$ Pattern ERGs, reflecting macular function, did not always show the same pattern of recovery as full field ERGs; there could be generalised improvement in retinal function shown by full field ERGs, but without a concomitant improvement in visual acuity or colour contrast sensitivity as a result of nonresponsive macular oedema.

To conclude, subjective symptoms and clinical signs are poor indicators of generalised retinal function in BCR. Electrophysiological examination provides a method of monitoring the efficacy of treatment, and may facilitate decisions on when to initiate therapy. Normalised retinal function can be achieved in BCR following treatment; it is assumed that this is beneficial to long term retinal health. The data suggest that monitoring of retinal function with electrophysiology after treatment has commenced is likely to improve efficiency of treatment and enable management decisions to be taken with more confidence. It is anticipated that this may lead to improved long term prognosis. A similar approach may be applicable to other retinal inflammatory diseases.

\section{Authors' affiliations}

G E Holder, A G Robson, C Pavesio, Moorfields Eye Hospital, London, UK

E M Graham, St Thomas's Hospital, London, UK

\section{REFERENCES}

1 Ryan SJ, Maumenee AE. Birdshot retinochoroidopathy. Am J Ophthalmol 1980;89:31-45.

2 Kaplan HJ, Aaberg TM. Birdshot retinochoroidopathy. Am J Ophthalmol 1980;90:773-82.

3 Priem HA, Oosterhuis JA. Birdshot chorioretinopathy: clinical characteristics and evolution. $\mathrm{Br} J$ Ophthalmol 1988;72:646-59.

4 Rothova A, Van Schooneveld MJ. The end stage of birdshot retinochoroidopathy. Br J Ophthalmol 1995;79:1058-9. 
5 Nussenblatt RB, Mittal KK, Ryan S, et al. Birdshot retinochoroidopathy associated with HLA-A29 antigen and immune responsiveness to retinal Santigen. Am J Ophthalmol 1982;94:147-58

6 Fuerst DJ, Tessler HH, Fishman GA, et al. Birdshot retinochoroidopathy. Arch Ophthalmol 1984;102:214-19.

7 Baarsma GS, Kiilstra A, Oosterhuis JA, et al. Association of birdshot retinochoroidopathy and HLA-A29 antigen. Doc Ophthalmol 1986;61:267-9

8 Baarsma GS, Priem HA, Kiilstra A. Association of birdshot retinochoroidopathy and HLA-A29 antigen. Curr Eye Res 1990;9(Suppl):63-8.

9 Priem HA, Kiilstra A, Noens L, et al. HLA typing in birdshot chorioretinopathy Am J Ophthalmol 1988;105:182-5.

10 Gaudio PA, Kaye DB, Crawford J. Histopathology of birdshot chorioretinopathy. Br J Ophthalmol 2002;86:439-63.

11 Szpak Y, Vieville JC, Tabary T, et al. Spontaneous retinopathy in HLA-A29 transgenic mice. Proc Natl Acad Sci 2001;98:2572-6.

12 de Courten C, Herbort CP. Potential role of computerized visual field testing for the appraisal and follow-up of birdshot chorioretinopathy. Arch Ophthalmol 1998;1 16:1389-91.

13 Oh KT, Christmas NJ, Folk JC. Birdshot retinochoroiditis: long term follow-up of a chronically progressive disease. Am J Ophthalmol 2002;133:622-9.

14 Priem HA, De Rouck A, De Laey JJ, et al. Electrophysiologic studies in birdshot chorioretinopathy. Am J Ophthalmol 1988;106:430-6.

15 Hirose T, Katsumi O, Pruett RC, et al. Retinal function in birdshot retinochoroidopathy. Acta Ophthalmol 1991;69:327-37.

16 Marmor MF, Holder GE, Seeliger MW, et al. Standard for clinical electroretinography (2004 update). Doc Ophthalmol 2004;108:107-14.

17 Bach M, Hawlina M, Holder GE, et al. Standard for pattern electroretinography. Doc Ophthalmol 2000;101:11-18.

18 Marmor MF, Zrenner E. Standard for clinical electro-oculography. International Society for Clinical Electrophysiology of Vision. Doc Ophthalmol 1993:85: 115-24.

19 Downes SM, Holder GE, Fitzke FW, et al. Autosomal dominant cone and cone-rod dystrophy with mutations in the guanylate cyclase activator 1A gene- encoding guanylate cyclase activating protein-1. Arch Ophthalmol 2001;119:96-105.

20 Calcagni A, Hogg CR, Spackman L, et al. Characterisation of the normal photopic electroretinographic responses to long duration stimuli evoked by a light emitting diode stimulator. Clin Neurophysiol 2001;112:1964-66.

21 Arden GB, Gunduz K, Perry S. Colour vision testing with a computer graphics system. Clin Vis Sci 1988;2:303-20.

22 Zacks DN, Samson CM, Loewenstein J, et al. Electroretinograms as an indicator of disease activity in birdshot retinochoroidopathy. Graefes Arch Clin Exp Ophthalmol 2002;240:601-7.

23 Holder GE. Pattern ERG and an integrated approach to visual pathway diagnosis. Prog Retin Eye Res 2001;20:531-61.

24 Bush RA, Sieving PA. Inner retinal contributions to the primate photopic fast flicker electroretinogram. J Opt Soc Am A 1996;13:557-65.

25 Alexander KR, Fishman GA, Peachey NS, et al. ON response defect in paraneoplastic night blindness with cutaneous malignant melanoma. Invest Ophthalmol Vis Sci 1992;33:477-83.

26 Lei B, Bush RA, Milam AH, et al. Human melanoma associated retinopathy (MAR) antibodies alter the retinal ON-response of the monkey ERG in vivo. Invest Ophthalmol Vis Sci 2000;41:262-6.

$27 \mathrm{Koh}$ AH, Hogg CR, Holder GE. The incidence of negative ERG in clinical practice. Doc Ophthalmol 2001;102:19-30.

28 Karpe G, Uchermann A. The clinical electroretinogram IV. The electroretinogram in circulatory disturbances of the retina. Acta Ophthalmol 1955;33:493-516.

29 Yotsukura J, Adachi-Usami E. Correlation of electroretinographic changes with visual prognosis in central retinal artery occlusion. Ophthalmologica 1993;207:13-18.

30 Dowling JE, Ripps H. Adaptation in skate photoreceptors. J Gen Physiol 1972;60:698-719.

31 Hood DC, Birch DG. Rod phototransduction in retinitis pigmentosa: estimation and interpretation of parameters derived from the rod a-wave. Invest Ophthalmol Vis Sci 1994;35:2948-61. 